\title{
Hot Habitats in Britain
}

\author{
T.J.C. Beebee
}

Britain has a mainly temperate climate, but there are some hot habitats, such as sand dunes, heathlands and shallow-water areas, which may be vital to the survival of certain species - Dartford warbler, sand lizard, natterjack toad are examples. The author suggests it is therefore vital to conserve extensive examples of these habitats to preserve the wildlife that depends on them. Unfortunately they are habitats that have suffered considerable destruction.

It is broadly true that the British Isles are subject to a maritime or Atlantic weather pattern, dominated by mild winters, cool summers and a moderately high rainfall. But exceptions exist in England, giving rise, in summer at least, to physical conditions and biological adaptations similar to those in more southerly climates. In particular, there are 'hot' habitats which maintain summer daytime temperatures much higher than those occurring over most of the country. These are most easily defined as zones lacking sufficient shade to depress open sunshine temperatures at more than a few inches above ground level. The essential factor is therefore the temperature differential between sun and shade, which on summer days in south-east England may be at least $7^{\circ} \mathrm{C}$ on land or in shallow water. ${ }^{1}$

Rainfall in the British Isles is derived mainly from frontal systems tracking in from the Atlantic. The west and north of the country receive the brunt of these fronts, and since by a geological coincidence much of the high land is in these regions, southern and eastern England are protected and tend to be drier. The importance of this is that the lesser cloud cover ensures more summer sunshine hours. In general terms, therefore, as is well known, south and east England usually enjoy warmer and sunnier summers than the rest of the islands.

This might have little biological significance were it not for the different types of habitat occurring within the region. From shortly after the last ice age until the advent of large-scale human activity some 3000 or so years ago, England was almost entirely forested, so that in summer there was effective and permanent shade at ground level, and it is primarily the presence or absence of shade in this country, with its small range of latitude, which dictates the thermal properties of a particular area in summer. From early times human activity has been directed to removing the native forest until, by the beginning of the 20th century, less than three per cent of the land was tree-covered. (The Forestry Commission has since had a slight effect in reversing this trend.) By removing shade on such a vast scale, it might be thought that 'hot' habitats would become the rule rather than the exception in England, but the effects of deforestation are not so simple.

First, forest clearance coincided with a general cooling of temperate climates that has persisted until modern times, which largely negated any overall warming effect of the deforestation. Secondly, the thermal and biological features of the cleared areas became strictly dependent on the precise use to which the land was put, and also on the local geology and topography. Thus agricultural land probably did not become a widespread 
'hot' habitat after tree clearance, for several reasons. Grazing, in the tirst instance, usually produces such closely cropped vegetation that little biological expansion - particularly of fauna - is possible, due to lack of cover; pasture land is often on damp or even waterlogged soil; arable farming subjects the land to gross disturbance - such as annual ploughing and reaping, and, recently, pesticides - which prevents the establishment of a stable ecosystem, and great efforts are made to maintain monocultures, of ten on a rotational system. Of course, farming has only recently attained its current efficiency, and the evolution of the present distinctive types of 'hot' habitat from agricultural land has been gradual in many instances.

\section{Three Main Types}

Sand dune systems are fairly common in the British Isles, and many may be unique in that their nature has not been dictated in any way by the hand of man. The shifting sand tends to preclude tree growth, though some recent conifer plantations have been successful, and the low shrub and marram grass covering is characteristic of an unshaded biotope with high summer ground temperatures. Particular dune systems are relatively short-lived - usually no more than a few hundred years - but since prevailing winds cause them to form in the same general areas, some stretches of coast may have had consecutive dune borders for many thousands of years. The dunes of south-west Lancashire, for example, parallel a ridge of Shirdley Hill sands a few miles inland which were derived from an earlier dune system.

Pollen analysis shows that one result of the deforestation 3000 years ago was the formation of vast tracts of heathland, with Calluna spreading over large areas. Tree regeneration was prevented by low-density livestock grazing and occasional fires. The old definition of heathland included virtually all 'wastelands' of low scrub, not necessarily dominated by heather but probably always characterised by low vegetation and therefore "hot'. Large areas of lowland England consisted of such terrain at least until the agricultural revolution, and there were extensive and contiguous heaths in East Anglia, the London basin, Surrey, Hampshire, Dorset and the lowland corridor of the Midlands, and chalk heaths on the Downs and elsewhere. Physically, heathland differs from grazing pasture in its better drainage, taller and less disturbed vegetation and (usually) poorer, large-grained soils.

Another 'hot' habitat is the freshwater one to be found in southern and eastern England in the extensive areas of low-lying land along the river valleys, including the grazing marshes of East Anglia, Kent, Sussex and of course the Fens. These may always have been warm places, but in their present form they are relatively new, the result of effective drainage dykes, dug in the last few hundred years. Terrestrial habitats in these places are typically agricultural, but the dykes themselves are unique in England. Unlike small farm ponds, dykes are regularly cleared out and tree growth prevented, so that they do not become shaded, and they are sufficiently small to warm up rapidly in the summer sun. They occur over such large areas that periodic clearance never affects more than a small area at one time, and habitat continuity is maintained.

What species characterise these 'hot' habitats and make them unique? We cannot easily consider flora, since plant species might well be selected by other 
factors such as soil type or light intensity. Some of the most abundant plants - hea ther or marram grass, for example - certainly are not thermally selected. On the other hand, a number of animal species have distribution patterns which strongly suggest thermal limitations and selection on this basis. Among the vertebrates, warm-blooded groups would not be expected to show much thermal selection, and generally do not do so. Nevertheless, the red-backed shrike Lanius collurio and the Dartford warbler Sylvia undata dartfordiensis are southern species which are commonest on or, in the latter case, virtually restricted to heathland habitat, and the wren Troglodytes troglodytes, though found throughout England and Scotland, is exceptionally abundant on heathland (C. R. Tubbs, pers. comm.). Dartford warblers and wrens suffer dramatic mortality in hard winters in Britain, and the shrike is a summer visitor.

'Hot' habitat selection is very marked in reptiles and amphibians on the edge of their range. Sand lizards Lacerta agilis occur only on southern heathlands and sand dunes in the north-west and the smooth snake Coronella austriaca is entirely restricted to heaths. Populations of the commoner British reptiles also tend to be much larger in these habitats. The natterjack toad Bufo calamita, a south-west European species, is restricted to hea ths and dunes and has also bred in marsh dykes where these adjoin suitable terrestrial habitats. This kind of habitat restriction for southern species of reptiles and amphibians is general in extreme north and north-west Europe, and can also be seen on the hea ths and dunes of north France, north Germany, Holland and Scandinavia. Other examples are the European tree frog Hyla arborea, introduced many times into Britain, which has formed only one persistent colony - around a heathland pond. The East European marsh frog Rana ridibunda was introduced to marsh dykes in Kent in 1935 and has since spread prodigiously but always within these areas. Repeated efforts to introduce it and its close relative, the edible frog $R$. esculenta to other habitats over the last 150 years have almost always ended in failure, usually without achieving any significant increase in numbers.

\section{Dragonflies, Scorpions and Water Beetles}

Some invertebrates also show probable thermal selectivity. Among dragonflies 26 of the 42 British species of Odonata, have been recorded from a single heathland marsh, a far greater diversity than occurs in any other type of habitat. The long water scorpion Ranatra linearis, though found throughout southern England, is rare outside heath ponds and marsh dykes, and the dytiscid water beetles Graphoderus cinereus and Dytiscus circumflexus are virtually restricted to marsh dykes and heathland ponds in south-east England. The former species is very rare, and it is interesting to note that the water composition of these habitats - mineral-deficient and acid on heath, rich and neutral or alkaline in the marsh dykes - could scarcely be more diverse, suggesting that other factors, probably thermal ones, may govern their distribution. The water beetle family Hydrophilidae is primarily a south European one, and its most striking member, the great silver water beetle Hydrophilus piceus is restricted in Britain to the marsh dykes of the south and east.

'Hot' habitats are thus of ten the home of species which, in their absence, 
could not survive in Britain. No doubt there are species in other groups which share these particular thermal needs.

\section{The Future}

It is difficult to be optimistic on the fate of these habitats in Britain. Dunes have suffered from holiday activities and many, for example in north Wales, have been almost entirely lost. Many slacks (freshwater dune pools) have vanished because of drainage schemes. Heaths have suffered enormously from building development, agricultural reclamation, afforestation and fires; only a small fraction remain unscathed. The shift to arable farming has resulted in the loss of large areas of marsh dykes, either directly or due to pesticides; the Fenland ditches provide an example of such devastation over a very large area. It is still not too late to conserve extensive samples of these habitats, with their associated fauna, but such action must come soon and the fundamental importance of 'hot' habitats to British wildlife diversity must be recognised.

\section{References}

1. BEEBEE, T.J.C. and BEEBEE, M.L. 1977. A quantitative study of natterjack toad Bufo calamita metamorphosis. Brit. J. Herpetol. In press.

Dr T. J. C. Beebee, University of Sussex, Brighton. Sussex BN1 9QG.

\section{Reports and Journals}

The 13th Annual Report of the Jersey Wildlife Preservation Trust includes an article by the Hon. Director, Gerald Durrell, on his trip to Mauritius, as a result of which the Jersey Zoo is now breeding two Round Island skinks, Gunther's gecko and the Rodrigues fruit bat, and one by Jeremy Mallinson, Zoological Director, on the pygmy hog Sus salvanius also being bred at Jersey.

The Effects of Fire on the Ecology of the Boreal Forest, with particular reference to the Canadian North, by John P. Kelsall, E. S. Telfer and Thomas D. Wright, Occasional Paper No 32 of the Canadian Wildlife Service, reviews the literature and concludes that fire is a long standing and the most important ecological factor in this type of forest. which is a fire-dependent ecosystem, and that the wildlife and vegetation have evolved and adapted to fire.

As part of its 1976-77 Wetlands Campaign, the Council of Europe has published a set of seven papers ranging from general discussion on the value of wetlands to specific, practical advice on conserving them. They average about 200 words. Free of both charge (and copyright) from European Information Centre for Nature Conservation, Council of Europe, B.P. 431, 67006 Strasbourg, Cedex, France.

Park and reserve boundaries are more of ten drawn for political or economic than for scientific reasons. Proceedings of a Regional Meeting on the Creation of a Co-ordinated System of National Parks and Reserves in Eastern Africa, Serengeti National Park. Tanzania, October 1974 (IUCN New Series Supplementary Paper No. 45) suggests changes that can bring closer alignment.

Ökologie und Verhalten des Banteng (Bos javanicus) in Java (Vol. 10, Mammalia Depicta, Paul Parey, Hamburg) is Ulrich Halder's report of his 17-month field study in Udjung Kulon and Baluran reserves, written in German with English and French summaries. Hunting and habitat destruction are threatening the banteng's survival, and he urges the need of an efficient guard system in the Baluran reserve and limited tourism to get money for management. 